\title{
Protein Enrichment of Cassava By-products Through Solid State Fermentation by Fungi
}

\author{
Eustace A Iyayi ${ }^{1 *}$ and Dorothy M. Losel ${ }^{2}$ \\ ${ }^{1}$ Department of Animal Science, University of Ibadan, Nigeria \\ ${ }^{2}$ Department of Animal and Plant Sciences, The University of Sheffield, \\ S10 2TN, Sheffield, U. K \\ * Corresponding Author
}

\section{Introduction}

Nigeria stands as the world's foremost cassava producer with about 26 million tones (FAO, 1993). The leaves and peels, which are by-products of harvesting and processing, constitute $25 \%$ of the whole plant. These by-products and the flour constitute a potential source of livestock feed ingredient. The utilization of cassava and it by-products for livestock feeding has long been realized. Various authors have reported their use for feeding poultry (Ravindran, 1991; Sarwat et al, 1988, Long and Adetola, 1983), Pigs (Iyayi, 1986; Iyayi and Tewe, 1988) and ruminants (Smith, 1988). But cassava will be most beneficial for feeding monogastric animals.

The major limitation in the use of cassava for monogastric feeding is its low protein content. The flour, for example, contains about $3.6 \%$ protein and the peels about $5.5 \%$. Though the leaves are fairly high in protein with an average value of $21 \%$, it is desirable for this level to be improved. Because of the low protein of cassava products, their use in animal feeding usually requires the supplementation of such diets. Protein enrichment of cassava through less expensive means is therefore desirable. Fungal fermentation has been identified as an inexpensive tool for increasing the protein level of substrates in solid state. The attractive characteristics in the use of microorganisms for single cell protein include (1) their fast growth rate even in semi solid and solid media; (2) their high level of protein; (3) their comparable good nutritional values and (4) their easy genetically modification to growth under specific conditions on particular substrates. This study investigated changes in the protein levels of cassava pulp (flour), peels and leaves following solid state fermentation with Aspergillus niger, Saccharmyces cerevisiae, Rhizomucor miehei and Mucor strictus.

\section{Materials and Methods}

Cassava pulp, peel and leaves were obtained from the Cassava Breeding Unit of the International Institute of Tropical Agriculture, IITA, Ibadan, Nigeria. After being washed, they were separately chopped into pieces and dried to constant weight. The dried samples were then milled and stored.

\section{Inoculation of Samples}

A niger, S. cerevisiae, R. miehei and $M$. strictus were obtained from the culture bank of the Department of Animal and Plant Sciences. The University of Sheffield, Sheffield, UK. The $A$.niger and R.miehei were subcultured on $2 \%$ cornmeal agar and the $S$. cerevisiae a yeast on a medium of $1 \%$ yeast extract, $2 \%$ peptone and $2 \%$ glucose in $250 \mathrm{ml}$ Erlenmeger flasks after autoclaving for
15 minutes at $1210 \mathrm{C}$. After subculturing, the plates were incubated at $30^{\circ} \mathrm{C}$ for 3 days. Spore suspensions were prepared in distilled water. About $30 \mathrm{gm}$ of the milled samples of leaves and peels were weighed into each of 3 sets of flask. The moisture was adjusted to about $25 \%$ and autoclaved. After sterilization. 3 flask containing either peel or leaves were aseptically inoculated with each of the arganism and property labeled. The $A$ niger and $S$. cerevisiae flasks were incubated at $35^{\circ} \mathrm{C}$. The $R$. miehei flasks at $40^{\circ} \mathrm{C}$ and the $M$. strictus flask at $15^{\circ} \mathrm{C}$. Samples were withdrawn from the $R$. miehei flasks at days 4,8 and 12 (because of the vigorous growing nature of this fungus); from the $A$ niger flasks at days $5,10,15$ and 20 and from the $S$. cerevisiae and $M$. strictus flasks at days 7.14 and 21. Withdrawn samples were freeze-dried and milled.

\section{Protein analysis}

TCA protein was estimated by the method of Lowry (1962) and percentage crude protein was verified by the method of AOAC (1984). Data were subjected to statistical t-test analysis and means separated by Duncan's multiple range test.

Table 1. Changes in protein of cassava pulp and peels following solid substrate fermentation with Aspergillus niger and Saccharomyces cerevisiae

\begin{tabular}{|c|c|c|c|c|c|c|c|c|}
\hline \multicolumn{6}{|c|}{ Aspergillus niger } & \multicolumn{3}{|c|}{ Saccharomyces cerevisiae } \\
\hline $\begin{array}{l}\text { Fermentation } \\
\text { period (days) }\end{array}$ & 0 & 5 & 10 & 15 & 20 & 7 & 14 & 21 \\
\hline Cassava pulp & $\begin{array}{l}3.60 \mathbf{a} \\
\pm 0.85\end{array}$ & $\begin{array}{l}8.10 \mathrm{~b} \\
\pm 1.22\end{array}$ & $\begin{array}{l}8.15 b \\
\pm 1.23\end{array}$ & $\begin{array}{l}8.40 \mathrm{~b} \\
\pm 1.25\end{array}$ & $\begin{array}{l}9.04 \mathrm{~b} \\
\pm 1.92\end{array}$ & $\begin{array}{l}7.58 \mathrm{~b} \\
\pm 1.01\end{array}$ & $\begin{array}{l}7.79 \mathrm{~b} \\
\pm 1.03\end{array}$ & $\begin{array}{l}7.91 \mathrm{~b} \\
\pm 1.08\end{array}$ \\
\hline Cassava peels & $\begin{array}{l}5.60 \mathbf{a} \\
\pm 0.95\end{array}$ & $\begin{array}{l}11.00 \mathbf{b} \\
\pm 2.66\end{array}$ & $\begin{array}{l}12.99 \mathbf{b} \\
\pm 2.80\end{array}$ & $\begin{array}{l}13.50 \mathrm{~b} \\
\pm 2.95\end{array}$ & $\begin{array}{l}14.14 \mathbf{b} \\
\pm 2.99\end{array}$ & $\begin{array}{l}15.22 b \\
\pm 3.00 \\
\end{array}$ & $\begin{array}{l}16.18 \mathbf{b} \\
\pm 3.05 \\
\end{array}$ & $\begin{array}{l}16.74 b \\
\pm 3.08 \\
\end{array}$ \\
\hline
\end{tabular}



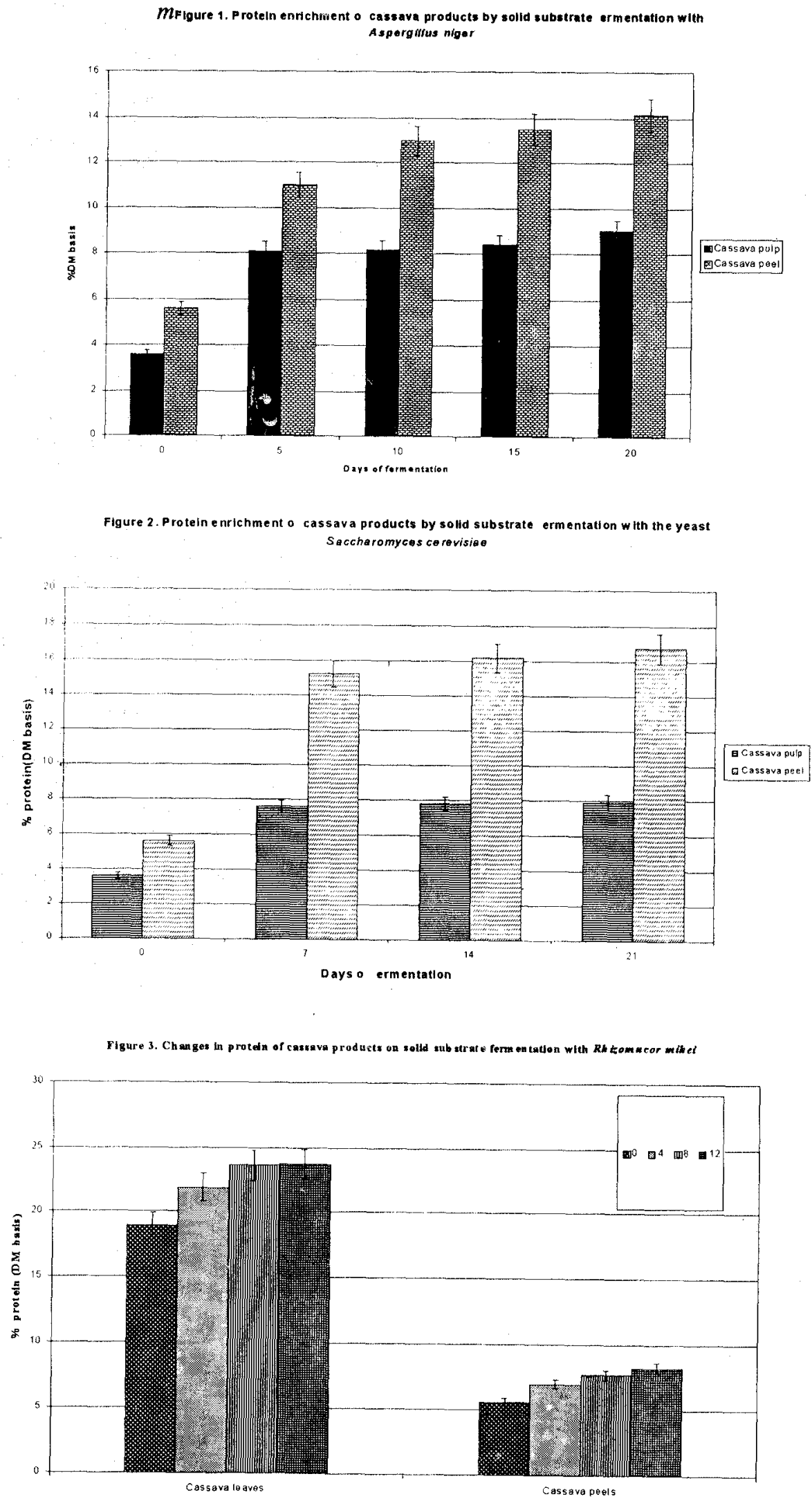

Table 2. Changes in protein of cassava leaves and peels following solid substrate fermentation with Rhizomucor michei and Mucor strictus

\begin{tabular}{lllllllll}
\hline & \multicolumn{3}{l}{ Rhizomucor miehei } & \multicolumn{5}{c}{ Mucor strictus } \\
\hline Fermentation & & & & & & & \\
period in days & 0 & 4 & 8 & 12 & 7 & 14 & 21 \\
\hline Cassava leaves & $18.97 \mathbf{a}$ & $21.89 \mathrm{~b}$ & $23.63 \mathbf{c}$ & $23.78 \mathbf{c}$ & $20.43 \mathbf{b}$ & $21.95 \mathbf{b}$ & 21.97 \\
& \pm 4.12 & \pm 5.02 & \pm 5.36 & \pm 5.74 & \pm 5.00 & \pm 5.01 & \pm 5.08 \\
& & & & & & & \\
Cassava peels & $5.60 \mathbf{a}$ & $7.02 \mathrm{a}$ & $7.73 \mathbf{a}$ & $8.26 \mathbf{a}$ & $6.51 \mathbf{a}$ & $8.19 \mathbf{a}$ & $9.54 \mathbf{b}$ \\
& \pm 0.95 & \pm 1.00 & \pm 1.02 & \pm 1.24 & \pm 0.99 & \pm 1.22 & \pm 1.96
\end{tabular}

Means with different letters on same row are significantly $(\mathrm{P}<0.05)$ different.
Results and Discussion

Changes in the protein level of cassava ralp and peels following inoculation with A.niger and S.cerevisiae are shown in igures 1 and 2 and Table 1. Changes in the leaves and peels on fermentation with R. miehie and $M$. strictus are shown in igures 3 and 4 and Table 2. Tables and 2 show significant increase $(\mathrm{P}<0.05)$ in the level protein caused by fermentation with th: respective fungi.

A. nige caused a significant iacrease $\left(\mathrm{P}^{2} 0.05\right)$ in the protein of peels after 20 days from $5.6 \%$ to $14.14 \%$ and of the pulp from $3.6 \%$ to 9.40 . S. cerevisiae caused a snificant increase $(\mathrm{P}<0.05)$ in the prote $x$ of peels after 7 lays of fermentat on to $15.22 \%$. Beyond this perioc anc up to day 21 , the protcin level rose non-significantly $(\mathrm{P}>0.05)$ to $16.14 \%$. The yeast significantly increased $(\mathrm{P}<0.05)$ tlie protein of the pulp from $3.6 \%$ to $7.58 \%$ after 7 days and beyond this day non-significantly $(\mathrm{P}>0.05)$ to $7.91 \%$. R. miehei caused a significant increase $(\mathrm{P}<0.05)$ in the protein level of the leaves within the first 7 days but there was no further significant increase $(P>0.05)$ in the protein of the peels on inoculation with the organism. $M$. strictus significantly $(\mathrm{P}<0.05)$ increased the protein of the leaves up to day 7 but beyond there was no further significant $(P>0.05)$ increase. The organism brought about significant increases $(\mathrm{P}<0.05)$ in the protein of the peels only by day 21 .

All the fungi showed potential to increase the protein of the cassava products. The yeast $S$. cerevisiae demonstrated the best ability to enrich the peels, with a change of $171.78 \%$ in 7 days and $192.85 \%$ atter 2.1 days. This was followed by $A$. niger, $M$. stricus and $R$ miehei in that order. But $A$. niger resulted in a higher percentage change in the protein level of the leaves. Results obtained for $A$. niger are comparable to those of Abu (1997) who reported similar findings using sweet potato in solid state fermentation. According to Wainright (1992), fermentation of cereals leads to improvement in protein content. The author reported that fermenting corn meal with the yeast $S$. cerevisiae and Candida trpoicalis increased the protein content from $7.7 \%$ to $8.9 \%$ and that the protein content can be further increased by adding malt extract to the meals. Balagopalan (1996) reported the potential 
VI Iguc 4, E frect of solid substrate ferraentution of cass ava products with Mucor strictus on their proteln contents

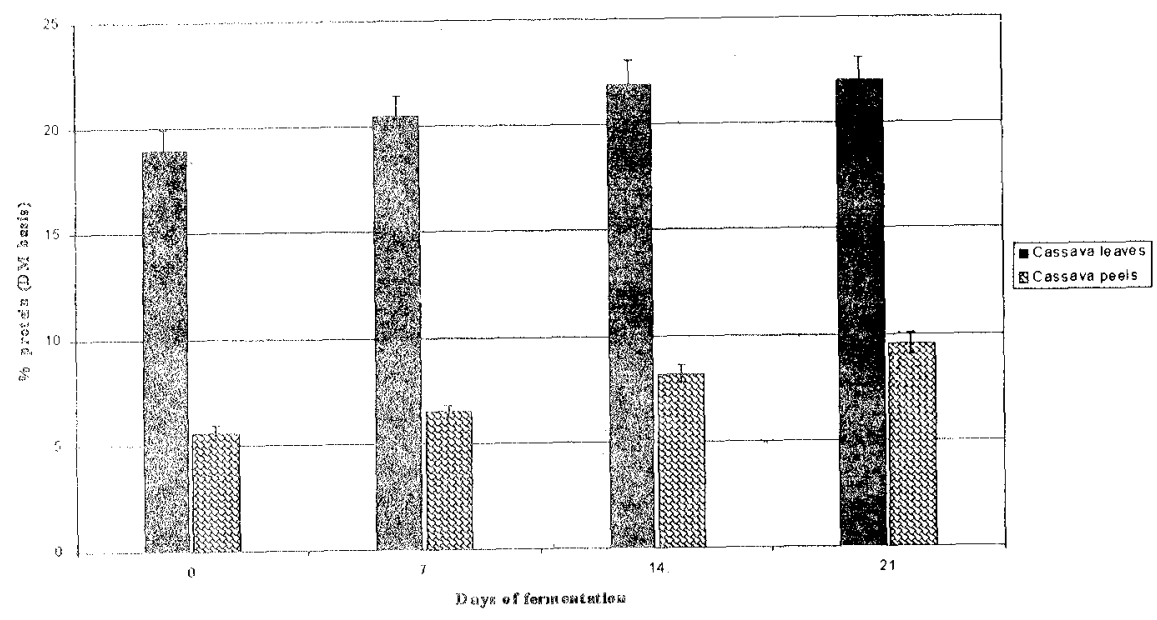

of most frugg to enrich the protein of cassava product. Similar studies by Essers (1994) showed the ability of hingi to curich the protein of cassava products.

In the present study, the optimum period for a good yicld of protein in the substrate lies between 12 to 15 days. Balagopolan (1996) reporied 12 days sis the optimum for some cassava products. The increase in protcin recorded in the present study is at par with those obtained by other workers reporting on solid sate ferncntation; Brook et al (1969), Marilal et al (1985) Daubresse et al (1987). The pcriod between 0 and 15 days represents the period when the growth of the microorganisns is most vigorous. Beyond this period, the microorganisms very quickly ne up the materia s the medium and gro th is slowed down. This oxplains why the increase in protein beyond a certain period for the respective organism is only slight. Adding boosters like malt extact as suggested by Waimight (1992) or molasses at the initial stage can ensure a further increase in protein content of the naterial being enriched.

\section{Aknowledgement}

The authows are grateful The Royal Socicty of Britain for funding this research; to the Cassava Breeding Unit, International Institute of Tropical Agriculture, ITTA, Ibadan, Nigeria for providing the cassava samples that were used for the studies and to the Department of Animal and Plant Sciences, The University of Sheffield, S10, 2TN, Sheffield, U. K for providing the facilities used for the studies.

\section{References}

Atbu O. A (1997). Biochemical characteristics and utilization of processed sweet potato (Ipomaea batatas (L) LAM for rabbit feeding Ph.D Thesis, University of Ibadan, Ibadan, Nigeria, 1997.

AOAC (1984) Association of Official Analytical chemists. Official methods of analysis, $12^{\text {th }}$ Edition, Washington $\mathrm{DC}$.

Ralagopalam, C. (1996). Nutritional improvement of cassava products using Microbial techniques, for animal feeding. Central Tuber Crops Research Publication, 1996.

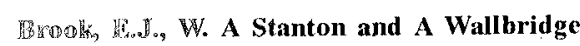
(1969) Fermentation methods for protein enrichment of cassava by solid substrate fementation in rural conditions fermentation. Acta Horticultural 375:217-224.

Daubresse, P, S. Nitanton wara, S. Gheyen and J. A Meyer (1987). A process for protein enrichment of cassava by solid substrate fermentation in rural conditions. Biotecthnol. Bioengy. 29:962-968.

Essers, A. J (1994) making safe flour from bitter cassava by indigenous solid substrate fermentation. Acta Horticultural 375:217 224.

FAO (1992). Food and Agricultural Oganisation, Production Year Book, 1992, FAO, Rome, Italy.

Iyayi E.A (1986) Effects of varying dietary cyanide and protein levels on the performance of growing pigs. Ph.D Thesis, University of Ibadan, Ibada. Nigeria. $306 \mathrm{p}$

Iyayi E.A. and O.O. Tewe (1988) Effect of protein deficiency on utilization of cassava peel by growing pigs. In : S.K. Haha, L Reynolds and G.N. Egbunike (eds). Cassava as .Livestock feed in Africa. Proceedings of the IITA/ILCA University of Ibadan workshop, 14-18 November, 1988, Pp 54-59.

Longe, O.G and J.A Adetola (1983) Metabolizable energy values of some Agricultural wastes and industria by-products for layers an their effects on gut dimenstion . J.Anim Farr R.J Randall (1951). Protein measurement with Folinphenol reagent. J. Biol Chem, 193: 265-275

Manila, V.;B . Narayanan and C. balagopal (1985). Amyloglucosidase and cellulase activity of Aspergillus niger in cassava starch factory wastes. In: Proceedings of the National symposium on production and utilzation of Tropical Tuber Crops, held at Trivandrum 2728, 1985, Pp21-213.

Ravindran, V. (1991). Preparation of Cassava lead product products and their use as animals feed. In Roots, Tubers, Plantain and Bananas in Animal Feeding January, 1991 Pp 111-126.

Sarwat, S. V. K. S. N. Akala and J. A Kategile (1988) Performance of growing finishing pigs with diets containing fresh cassava leaves and roots E. Afri. Agric. For J. 53: 111-115.

Wainright, M (1992) An introduction to Fungal Biotechnology. Wiley Biotechnolgy Series. Wiley Publishers. U.K. 202p. 